\title{
Establishing and maintaining a toxin-free pasture: a review
}

\author{
D.E. HUME \\ AgResearch, Grasslands Research Centre, Private Bag 11008, Palmerston North \\ humed@agresearch.cri.nz
}

\begin{abstract}
This paper reviews how new pastures may become contaminated with perennial ryegrass (Lolium perenne) infected with wild-type fungal endophytes (Neotyphodium lolii). These wild-type endophyte strains may be toxic to domestic livestock. Sources are from seed (natural reseeding, buried seed, sown seed, in dung, hay, carried on farm machinery) and survival of existing infected ryegrass plants. In particular, seed in soil and dung are reviewed. Contamination may occur both pre- and postestablishment. It is recommended that steps should be taken to minimise contamination from all sources when establishing new pastures. Although normal establishment practices for successful rapid establishment of weed-free pastures (e.g., cropping, fallow, herbicides) will minimise the risk of contamination, a number of cases highlight that extra time (e.g., 18-24 months planning rather 612 months) and consideration of all sources of contamination is needed to minimise risk. Once established, further measures should be taken to prevent seed being transferred in dung or hay. This has implications when establishing pastures with endophyte-free ryegrasses, ryegrasses with selected non-toxic endophytes, a new ryegrass cultivar, or other grasses (e.g., tall fescue), whether for grazing by animals or for seed production.
\end{abstract}

Keywords: endophyte, endophyte survival, faeces, Lolium perenne, natural reseeding, Neotyphodium lolii, pasture establishment, perennial ryegrass, seed burial, seed survival, tall fescue

\section{Introduction}

There are a number of reasons for renewing or renovating pastures, and various techniques are used (Langer 1977). Essentially the aim is to successfully establish the sown species, through maximising the emergence of sown seeds and rapid early seedling growth, to achieve adequate plant and tiller numbers for a productive sward. Destruction of the existing vegetation is a key success factor (White 1977), especially with no-tillage establishment techniques such as direct drilling and oversowing. In many cases, incomplete kill or ingress of perennial ryegrass (Lolium perenne $\mathrm{L}$.) into new pastures is not a concern as this is usually the grass species that most farmers are sowing (Sangakkara et al. 1982; Belgrave et al. 1990) and want to increase in their pastures. However when establishing ryegrasses with no endophyte or selected non-toxic endophytes, or with other grass species that contain no endophyte such as commonly used cultivars of tall fescue, a greater importance needs to be placed on removing all existing ryegrass from the paddock. This review, therefore, primarily concentrates on ways in which new pastures may become contaminated, preand post-establishment, with ryegrass that is infected with endemic wild-type fungal endophyte (Neotyphodium lolii). These endophyte strains may be toxic to grazing livestock (Fletcher et al. 1999).

\section{Significance}

\section{Pasture - perennial ryegrass}

In the past, relatively little attention has been paid to the situation where ryegrass is to be established into a "run-out" ryegrass pasture. In general, the origins of the ryegrass (i.e., sown seed or existing ryegrass) in the new pasture has not been of concern as long as the end result was ryegrass dominant. However, eliminating the existing ryegrass is important if the purpose is to obtain a "toxin-free" ryegrass pasture (free of wildtype ryegrass endophyte), or the advantages of a newer ryegrass cultivar are to be fully realised. Ryegrass cultivars are available as endophyte-free $(\leq 5 \%$ endophyte), or with selected endophytes either free of lolitrem B (the prime endophyte toxin causing ryegrass staggers) e.g., currently available in "Endosafe" Greenstone, or free of both lolitrem B and ergovaline (an endophyte toxin causing heat stress) (Fletcher 1999). Endophyte-free cultivars may be used where improved animal health and productivity are considered more important than pasture persistence e.g., dairy production under irrigation in North Canterbury (Sutton 1996), or where endophyte is not necessary for pasture persistence e.g., Southland (Widdup \& Ryan 1992; Eerens et al. 1998; McCorkindale 1999). Selected endophytes have the advantage of protecting ryegrass from a number of insect pests (Popay et al. 1999) and yet have major 
advantages for animal health and production (Fletcher 1999).

The main problem in determining if contamination with resident ryegrass has occurred is that it is difficult, if not impossible, to visually distinguish sown compared with resident volunteer ryegrass in a new ryegrass pasture. The use of biochemical analyses of the plant or endophyte (Barker et al. 1997) can indicate these proportions. For example, in a dry hill country evaluation of grass species in the Wairarapa, establishment of resident ryegrass in non-ryegrass plots raised the possibility that the Nui ryegrass plots were a mixture of resident and Nui ryegrass (Lancashire \& Brock 1983; Sanders et al. 1989). From seedling counts this was estimated to be $18 \%$ of seedlings established 6 weeks after sowing. By using 'biochemical markers' in ryegrass through enzyme electrophoresis, Sanders et al. (1989) showed that 6 years after sowing only 5$44 \%$ of the ryegrass present (depending on treatment) was actually the sown cultivar of Nui. Similarly, McCorkindale (1999) reported that using microscope tests for endophyte presence in ryegrass showed that incomplete kill or natural reseeding resulted in varying proportions $(0-23 \%)$ of contamination with wild-type endophyte-infected ryegrass in pastures sown with endophyte-free ryegrass.

In New Zealand, selection pressures, primarily from insect pests such as Argentine stem weevil, are such that endophyte occurrence in a pasture increases with time as endophyte-free tillers are preferentially damaged compared to endophyte-infected tillers (Prestidge et al. 1982; Hume 1993). Thus a pasture with a small proportion of endophyte-infected ryegrass tillers at sowing may quickly convert (over 1 to 2 years) to pastures with most of the ryegrass tillers infected with endophyte and possibly a low content of ryegrass (Prestidge et al. 1984; Prestidge et al. 1985; Popay et al. 1999). Similar increases in endophyte infection can occur with tall fescue in the USA (Shelby \& Dalrymple 1993) and New Zealand (Easton \& Cooper 1997). A small contamination in an endophyte-free pasture may therefore increase and become a significant amount with time.

\section{Pasture - other grasses}

Increased use of alternative grass species in New Zealand (Lancashire 1978) for dryland situations has highlighted the high contents of ryegrass that can occur in these pasture types in small plot research trials and on-farm (Lancashire \& Brock 1983; Smith et al. 1993). Tall fescue (Festuca arundinacea Schreb.), phalaris (Phalaris aquatica L.), cocksfoot (Dactylis glomerata L.) and prairie grass (Bromus willdenowii Kunth) pastures may be sown to overcome the relatively poor tolerance of ryegrass to insect pests and drought, provide a different seasonal distribution of pasture production, or provide a better quality pasture either through greater clover content (e.g., tall fescue/white clover pastures) or lack of animal toxins that are produced by ryegrass infected with wild-type endophyte (Lancashire 1978; Lancashire \& Brock 1983). However some of these grasses have poor establishment characteristics such as slow early seedling growth (e.g., tall fescue; Brock 1983) or requirements for specific conditions of temperature and moisture for rapid establishment (e.g., prairie grass; Culleton \& McCarthy 1983; Falloon \& Rolston 1990). The rapid establishment characteristics of ryegrass (Lancashire \& Brock 1983) can result in small amounts of ryegrass at establishment becoming significant proportions of the pasture at later dates.

For example, a 3\% content of ryegrass in autumn/ winter following an autumn establishment of tall fescue, had increased to $39 \%$ ryegrass in the following summer (Hume \& Lyons 1993; Hume unpublished data). In this experiment, treatments which gave the highest emergence of tall fescue seedlings and subsequent tall fescue productivity had the lowest contents of ryegrass, which at least in part may have been due to greater competition of tall fescue with the ryegrass. This emphasises the need to use establishment techniques that not only minimise contamination from resident ryegrass but also ensure high numbers of established seedlings and early pasture growth. In dry hill country in the Wairarapa, Lancashire \& Brock (1983) found that a considerable strike of resident ryegrass (240 seedlings $/ \mathrm{m}^{2}$ ) resulted in strong competition with several autumn sown dryland grasses over the first winter and spring. Thus 2 years after sowing, contents of ryegrass were $41 \%$ in tall fescue, $48 \%$ in prairie grass and $54 \%$ in phalaris plots, and only in 'Wana' cocksfoot plots was resident ryegrass at the same level as when originally sown (approximately $20 \%$ ). The competitiveness of Wana to resident ryegrass has also been noted in paddock demonstrations in the east coast of the North Island (Smith et al. 1993). In prairie grass swards, a number of studies have noted an ingress of ryegrass. This was considered to jeopardise the long-term persistence of prairie grass, possibly through preventing natural reseeding and a decline in vigour of prairie grass plants (Alexander 1985; Boom $\&$ Sheath 1990).

\section{Seed production}

In the seed industry, "providing consumers with seed of high cultivar and physical purity" have been the prime aims of the New Zealand seed certification scheme since its voluntary introduction in 1929 (Eaden 1980; Hadfield \& Wynn-Williams 1983). One of the criteria to achieve cultivar purity has been the time interval between successive crops of the same species 
and different cultivars of the same species (AgriQuality NZ 1999). This has received most attention in the case of legumes, as these can form hard seeds that at a later date can germinate and contaminate future crops (Clifford et al. 1985; Lancashire et al. 1985). The required interval between successive crops of different white clover (Trifolium repens L.) cultivars is therefore 5 years. The interval between crops of ryegrass is less (2 years) as it does not form a hard seed, but contamination from seed dropped at harvest is an important issue (Archie \& Rowarth 1994). Since 1991, the certification scheme has also treated each endophyteryegrass cultivar association as if it was a new cultivar in order to maintain purity of seed lots for endophyte strain or endophyte absence (Rolston 1993; AgriQuality NZ 1999). A voluntary higher standard for certification of novel endophytes is currently being applied by seed companies (Rolston pers. comm.).

\section{Sources of contamination by wild-type endophyte- infected ryegrass}

Contamination of a new pasture with wild-type endophyte-infected ryegrass can occur through ryegrass seed and vegetative ryegrass plants. Endophyte is not transferred with pollen. Seed may (a) result from natural reseeding occurring before renovation of the pasture, (b) be carried in by animals (e.g., livestock, birds) and/ or the farmer (e.g., hay feeding, machinery), and (c) be in the sown seed. Vegetative ryegrass plants will occur primarily through the incomplete kill of existing pasture.

\section{Natural reseeding and buried seed}

Natural reseeding of ryegrass can occur from late spring (main period of seedhead production) to late summer (aftermath seedheads). Perennial ryegrass seed has a short-term dormancy (post-harvest dormancy) forming a transient seed bank present during the summer (Thompson \& Grime 1979). As conditions become cooler and moist, the majority of seed germinates in the autumn-early winter period (Hume \& Barker 1991) or earlier (L'Huillier \& Aislabie 1988) depending on rainfall (Hume et al. 1999). Seedlings then colonise any gaps in the pasture created by seasonally-predictable pasture damage and death caused by summer-autumn drought or insect pests e.g., porina. These are common features of many grass species (Froud-Williams et al. 1984). Natural reseeding as a means of deliberately regenerating ryegrass pastures through deferred grazing, has therefore been suggested in dairy production systems in Taranaki (McCallum et al. 1991) and Waikato (L'Huillier \& Aislabie 1988), and sheep grazed pastures in SW Victoria, Australia (Waller et al. 1999). Studies in dry hill country have also suggested that continual small annual inputs from natural reseeding of ryegrass may be significant in maintaining ryegrass swards when considered cumulatively over a number of years and can be as high as $31 \%$ of the total ryegrass tillers (Hume \& Barker 1991; unpublished data).

Ryegrass seed that reaches the soil surface either from natural reseeding or seed carried in hay or straw fed out to animals, may become buried in the soil. This burial may occur through a number of processes, e.g., farm cultivation; activity of earthworms (ingestion), ants, and rodents; surface earthworm casts (Matthew et al. 1989; Hay 1994); treading (pugging) by livestock; erosion; movement by water, wind, or gravity into cracks caused by drying of the soil (Garwood 1989). Buried ryegrass seed may be returned to at or near the soil surface by these same processes and may germinate and emerge to form new plants. Buried seed generally has a greater survival (increasing with depth of burial) compared with seed on the soil surface (Froud-Williams et al. 1984). This may be mediated through lower temperatures and lower daily temperature fluctuations, and less light and oxygen (Simpson 1990). Seeds also need certain characteristics to survive in the soil and so contribute significantly to a reservoir of buried seed. Perennial ryegrass has few of these characteristics, showing little post-harvest dormancy and few stimulatory factors for germination. In broad ecological terms, it is therefore considered to have "poor" survival as a buried seed only forming a short-lived seed in the soil (Chancellor 1978; Thompson \& Grime 1979; Thompson \& Grime 1983; Williams 1983). This is in keeping with perennial ryegrass reproducing primarily by vegetative means (tillering) (Rice 1989). However, small amounts of seed can be found 6-12 months after the depositing of seed in summer (Thompson \& Grime 1979; L'Huillier \& Aislabie 1988; Hume, unpublished data), with some studies showing survival after burial of 1-2 years (Harris 1961; Roberts 1986; Hume et al. 1999) and up to 4 years (Rampton \& Ching 1970; Lewis 1973) depending on soil type and ryegrass cultivar. Survival for these time periods may only be $0.1 \%$ but levels of $22 \%$ after 4 years burial have been recorded.

\section{Sown seed}

Most cultivars of perennial ryegrass are available as Nil endophyte ( $\leq 5 \%$ viable endophyte-infected seed), or high endophyte $(>70 \%$ viable endophyte-infected seed). Seed is also sold as low endophyte but with no specified level or range of $\%$ endophyte infection. The dangers of using this class of seed has been highlighted by McCorkindale (1999). In this case, use of low endophyte seed resulted in endophyte levels ( $82 \%$ and $58 \%$ tillers endophyte-infected) that were higher than those in the pastures before renovation $(68 \%$ and $42 \%$, 
respectively). Using low endophyte seed was therefore considered unacceptable, as the aim of the pasture renovation programme was to remove endophyte from the South Otago farm. The use of certified seed will also ensure the purity of selected endophytes as the certification scheme treats each endophyte-ryegrass cultivar association as if it was a new cultivar. An essential step in the re-establishment of any ryegrass pasture must therefore be to obtain a recent Purity and Germination certificate for the ryegrass seed which also states the percentage of viable endophyte-infected seed.

\section{Transfer of seed by animals}

It is possible for animals (including domestic livestock, birds, rabbits) to transfer seed either attached to their bodies (e.g., wool, hides, hooves) or when eaten and deposited in dung (Watkin \& Clements 1978). The passage of viable seed through the digestive tract is known to occur for a range of plants. It has been studied in relation to survival and transfer of undesirable (weed) seeds (e.g., Piggin 1978; Watkin \& Clements 1978) and as a method of distributing desirable forage plants (e.g., Hessberg 1932; Burton \& Andrews 1948; Lehrer \& Tisdale 1956) such as white clover in New Zealand hill country (Suckling 1952). Seed viability generally declines after passage through the gut but this varies widely with animal species (Harmon \& Keim 1934; Lehrer \& Tisdale 1956; Simao Neto et al. 1987), diet quality (Jones \& Simao Neto 1987) and plant species (Simao Neto et al. 1987). Viability may be improved for some seeds, especially for legumes that have hard seed coats (Ozer 1979; Simao Neto \& Jones 1987; Suckling 1952).

Only a few studies have investigated the passage of ryegrass (Italian, perennial, L. rigidum Gaud.) seed through the gut of a grazing animal. Survival may be less than 1\% (Yamada \& Kawaguchi 1972; Gramshaw \& Stern 1977; Fletcher \& Rolston unpublished data), however in some situations this may be up to $36 \%$ for perennial ryegrass (Lennartz 1957) and thus represent a significant number of seeds. In late summer in Northland, Betteridge et al. (unpublished data) recorded 204 viable ryegrass seeds $/ \mathrm{kg}$ moist dung from cattle grazing a ryegrass-white clover pasture. With measurements of herbage intake and dung output (Trial 1, Betteridge et al. 1986), this was equivalent to depositing 53 viable ryegrass seeds $/ \mathrm{m}^{2}$. In Manawatu hill country, Suckling (unpublished data) recovered seed from dung of cattle and sheep and found 129 and 46 viable ryegrass seeds/ $\mathrm{kg}$ of moist dung, with germination of $36 \%$ and $28 \%$, respectively. Using assumed values of pasture intake, digestibility and dry matter content, this may be equivalent to 32 and 8 viable seeds $/ \mathrm{m}^{2}$, respectively. Both these New Zealand studies used pastures that had considerable reproductive development, as the intent was to assess the use of grazing animals to disseminate viable seed to other areas of a farm (Suckling 1952; Suckling 1965).

Under intensive dairy grazing in the Waikato, van Vught \& Thom (1997) recorded ryegrass seed germinating in dung pats ( 3 per pat). It was presumed that mature aftermath seedheads of ryegrass were eaten by the dairy cows over summer. These seeds germinated following the autumn rains. Further observations over 2 years have confirmed these initial findings with considerable variation between years (Burggraaf \& Thom unpublished data). Although the numbers were low, estimated to be equivalent to $0.47 \mathrm{seeds} / \mathrm{m}^{2}$ (van Vught \& Thom 1997), this work highlighted that seed in dung is a source of contamination in dairy production systems.

Comparative studies indicate that cattle digest fewer seeds than sheep (Harmon \& Keim 1934; Simao Neto et al. 1987). This may be due to less damage to seed caused by chewing in cattle, and a larger particle size of digesta leaving the rumen of cattle than sheep (Uden \& van Soest 1982; Ulyatt et al. 1986) associated with substantial differences in rumen motility between these animal species (Waghorn \& Reid 1984; Waghorn et al. 1986). Increasing diet quality also increases amounts of viable seed passed, possibly through increasing the rate of passage through the gut and decreasing the rumination time (Jones \& Simao Neto 1987). Other factors (e.g., level of feed intake, lactation, ambient temperature) that increase the rate of passage of feed through a ruminant may be expected to increase the survival of viable seed. Thus for example, it may be expected that in summer, lactating dairy cows may pass more viable seed than dry sheep (ewes) grazing the equivalent pasture, due to aspects such as fundamental differences in digestion between these animal species and greater selective grazing behaviour of sheep (Hodgson et al. 1994).

Survival of endophyte in seed that has passed through the gut of an animal must also be considered. This has come to the attention of USA researchers through "inexplicable foci of endophyte infestation" occurring in endophyte-free tall fescue pastures (Shelby et al. 1989; Shelby \& Schmidt 1991). The endophyte (Neotyphodium coenophialum) in tall fescue is more sensitive to digestive tract conditions in steers than the seed viability (Siegel et al. 1984; Shelby \& Schmidt 1991). For example (Shelby \& Schmidt 1991), recovery in dung of a single meal of seed peaked at 22 hours after feeding for viable seed and viable endophyte-infected seed, but the last viable seed appeared 84 hours after feeding while the last viable endophyte-infected seed appeared at 38 hours. Endophyte infection declined for all viable seed passed by the animal, being $12 \%$ on average down from an initial infection of $98 \%$. Similar 
observations have been made for sheep fed endophyteinfected perennial ryegrass seed in New Zealand (Fletcher \& Rolston unpublished data) (80\% and 25\% viable endophyte in seed fed and in dung, respectively). However it should be noted that Shelby \& Schmidt (1991) recorded that under ad lib. grazing in the field, dung from both steers and horses contained tall fescue seedlings that were $85 \%$ and $89 \%$ (range 67-100\%) infected with viable endophyte, respectively, which is well beyond what would have been predicted from the single meal of seed fed to a steer.

Seed deposited in dung will decline in viability with time (Lennartz 1957), but this is minimal in comparison to the decline that occurs with passage through the animal's gut (Yamada et al. 1972). Relative decline in the viability of endophyte in deposited dung has not been assessed. Van Vught \& Thom (1997) have recorded $40 \%$ of the seedlings germinating in dung pats as being endophyte infected, but the endophyte infection of the seed ingested was unknown. Once seeds are deposited in the field in dung, seedlings may emerge over an extended period (e.g., 6 weeks, Yamada et al. 1972) and subsequent plant survival may be enhanced by the gap that is created in the pasture canopy by the dung pat and the fertility from the dung (Shelby \& Schmidt 1991).

The time taken for viable endophyte-infected seed to pass through the gut is important if "quarantine periods" are to be used to prevent livestock from transferring seed infected with wild-type endophyte via the dung. For Italian and perennial ryegrass, peak output of viable seed in dung occurs 1-2 days after feeding and in general most viable seed has passed through the gut 3-4 days after feeding. After 2 days, increasing time of passage through the gut results in greatly reduced seed viability (Yamada \& Kawaguchi 1971; Yamada \& Kawaguchi 1972). Shelby and Schmidt (1991) recommended 3 days for steers eating endophyte-infected tall fescue, and a similar period may be appropriate for endophyte-infected perennial ryegrass in New Zealand (Fletcher \& Rolston unpublished data).

The relative importance of depositing viable endophyte-infected ryegrass seed via dung in a paddock, either during the pasture renovation or after establishment, is unclear. Even though the New Zealand studies of Suckling and Betteridge et al. indicate high amounts of viable seed deposited, these values are only equivalent to sowing $0.2-0.6 \mathrm{~kg}$ ryegrass seed/ha which is small in comparison to establishing a new ryegrass pasture with sowing rates of $15-20 \mathrm{~kg}$ seed/ha. However, if this seed establishes earlier than the sown seed (Hume $\&$ Lyons 1992), or is a continual input over a number of years, then seed in dung may contribute to an increase in the content of wild-type endophyte-infected ryegrass in a pasture.

\section{Transfer of seed by farmers}

The feeding of hay or straw made from ryegrass infected with wild-type endophyte could potentially be the greatest source of seed to contaminate a pasture. This applies equally to pre- and post-pasture establishment. Seed may also be transferred on farm equipment such as trailers, seed drills and hay making machinery. Seed certification procedures also highlight that seed transfer by equipment and straw are ways in which contamination can occur (AgriQuality NZ 1999). Siegel et al. (1984) attributed the occurrence of endophyte in an endophyte-free tall fescue pasture to seed shattering as machinery and materials were moved across the boundary with a neighbouring endophyte-infected pasture during seed and aftermath harvesting operations.

\section{Vegetative plants}

The proportion of existing ryegrass plants in the pasture that are not killed before sowing will clearly have a direct and possibly substantial effect on the contamination of the new pasture. These plants will already have an established root system and therefore a strong competitive advantage over the sown ryegrass that is establishing from seed. The establishment procedure and technique chosen will determine to what extent the existing ryegrass in the paddock is removed. As an extreme, this is best illustrated in oversowing studies in hill country, where a high degree of suppression of resident vegetation, usually only effectively achieved through the use of herbicides, is a key factor in establishing the oversown grasses and the proportion to which they contribute to yields (Hume \& Chapman 1993). Overdrilling (direct drilling) with no herbicide will clearly result in little reduction in vegetative plants in comparison to a new pasture which is sown after a summer forage crop involving cultivation and/or herbicides. Farmers must ensure that cultivation techniques are thorough, burying and killing all turf, and this may also require herbicide use (Hume \& Lyons 1992; Hume \& Lyons 1993; McCorkindale 1999). Double herbicide spraying rather than a single spray to control vegetative ryegrass plants, and germinating seed, appears to be essential if only herbicides are being used to kill the existing sward (van Vught \& Thom 1997; McCorkindale 1999).

\section{Establishment methods}

\section{Cultivation and direct drilling}

In general, cultivation promotes the germination of buried seed (Rice 1989), encouraging the depletion of seed banks in arable areas (Champness \& Morris 1948). Cultivation may place ryegrass seed at a shallow depth $(1-2 \mathrm{~cm})$ providing ideal temperature and moisture 
conditions for germination, either through burying surface seed or bringing up deeply buried seed. These germinating seeds can then be killed through a further cultivation or a herbicide spray. "Deep" burial of surface seed (e.g., deep ploughing to $15 \mathrm{~cm}$ ) may result in enforced seed dormancy due to depth of burial and the formation of a seed bank. As long as this seed is not returned to the soil surface, and considering the relatively short life of buried ryegrass seed, this may be an effective way of reducing large amounts of seed that are on the soil surface. Overall it is expected that the greater the number of cultivations and number of crops that are sown before establishing a new pasture, the greater the chances of depleting any buried seed of ryegrass that may be present, killing vegetative plants, and preventing new seed input from natural reseeding.

Hume \& Lyons (1992) found that sowing into a cultivated seed bed in comparison to direct drilling reduced the number of ryegrass seedlings arising from natural reseeding/buried seed and could also reduce the size of these seedlings (tillers/seedling) by up to 6fold. On-farm demonstrations of drought tolerant pastures in the dry east coast (Milne et al. 1993; Smith et al. 1993) also found that cultivation reduced contamination with ryegrass. However, the mechanism for this is unclear as cultivated seed beds also had a higher seedling emergence of sown seed thus a more competitive sward to minimise ryegrass contamination, a key factor in reducing contamination post-sowing (Hume \& Lyons 1993).

\section{Choice of method}

Methods of establishment, the sequence and number of steps and timing, will vary widely influencing the degree to which ryegrass infected with wild-type endophyte is removed or minimised in the new pasture. Methods should consider what impact they will have on preventing/reducing natural reseeding, buried seed and vegetative plants, or a combination of these. It may be difficult to isolate what is actually happening in a particular situation. For example, van Vught \& Thom (1997) identified all these factors, as well as dung in seed, as being contributors to contamination in a new endophytefree pasture. In the Manawatu, Hume \& Lyons (1992) identified managements needed to reduce contamination from natural reseeding over a 6-month period before an autumn sowing. These included hard grazing, silage crop, and summer fallow. However, none of these treatments completely eliminated seedlings arising from natural reseeding/buried seed. Contamination in a similar trial in southern Hawke's Bay highlighted the need to consider methods that started to prepare paddocks 18 months rather than 6 months before an autumn sowing (Hume \& Lyons 1993), as have other trials (Alexander
1985; Easton \& Couchman 1999). Currently at Winchmore Research Station such a study is investigating a range of establishment methods some of which cover a period of up to 2 years before sowing the new pasture (Sutherland \& Fletcher pers. comm.).

\section{Conclusions}

This review has outlined possible pathways by which new pastures may become contaminated with ryegrass infected with toxic wild-type endophyte. Prevention of contamination by good preparation of the paddock before sowing is a key factor, as it is in general for the successful establishment of any pasture (Hume \& Fraser 1985; Milne et al. 1993). Preparation should

- kill all existing vegetative ryegrass plants either by repeated cultivations and/or herbicides,

- prevent natural reseeding,

- deplete any buried ryegrass seed through cultivation or time,

- prevent seed entering via dung, hay/straw, sown seed or machinery, and

- provide a seedbed that favours rapid establishment of the sown pasture (e.g., fertile, moist, fine, weedfree) as this will also reduce the proportion of contaminating ryegrass in the new pasture.

The time taken and methods to achieve this will vary. Evidence from a number of cases indicates that a paddock preparation of 2 years may be needed to ensure that natural reseeding is prevented for 2 seasons and that buried seed is reduced particularly in summer-dry environments. Contamination after sowing can be reduced by preventing seed entering via hay/straw, dung or machinery.

\section{ACKNOWLEDGEMENTS}

Vicki Burggraaf, Errol Thom, Phil Rolston, Lester Fletcher, Keith Betteridge, and Deric Charlton (access to Eddie Suckling's data) for access to unpublished data and observations.

\section{REFERENCES}

AgriQuality NZ 1999. Seed Certification 1999-2000. Field and Laboratory Standards. AgriQuality New Zealand, Christchurch. 103 pp.

Alexander, R.T. 1985. Effect of sheep grazing regime on performance of Matua prairie grass. Proceedings of the New Zealand Grassland Association 46: 151156.

Archie, W.J.; Rowarth, J.S. 1994. Management practices to ensure minimum contamination in seed crops 
when changing cultivars of perennial ryegrass (Lolium perenne L.). Proceedings of the Agronomy Society of New Zealand 21: 83-85.

Barker, D.J.; Christensen, M.J.; Wever, C. 1997. Application of endophyte allozyme analysis to Lolium perenne population ecology in hill country pasture. pp. 41-43. In: Neotyphodium/Grass Interactions. Eds. Bacon, C.W.; Hill, N.S. Plenum Press, New York \& London.

Belgrave, B.R.; Watt, P.C.; Brock, J.L.; Wewala, S.; Sedcole, J.R. 1990. A survey of farmer knowledge and use of pasture cultivars in New Zealand. New Zealand Journal of Agricultural Research 33: 199211.

Betteridge, K.; Andrewes, W.G.K.; Sedcole, J.R. 1986. Intake and excretion of nitrogen, potassium and phosphorus by grazing steers. Journal of Agricultural Science, Cambridge 106: 393-404.

Boom, C.J.; Sheath, G.W. 1990. Effects of soil characteristics and spring management on the persistence of 'Grasslands Matua' prairie grass. Proceedings of the New Zealand Grassland Association 52: 241-245.

Brock, J.L. 1983. 'Grasslands Roa' tall fescue: a review. Proceedings of the New Zealand Grassland Association 44: 74-80.

Burton, G.W.; Andrews, J.S. 1948. Recovery and viability of seeds of certain southern grasses and lespedeza passed through the bovine digestive tract. Journal of Agricultural Research 76: 95-103.

Champness, S.S.; Morris, K. 1948. The population of buried viable seeds in relation to contrasting pasture and soil types. Journal of Ecology 36: 149-173.

Chancellor, R.J. 1978. Grass seeds beneath pastures. Changes in Sward Composition and Productivity. British Grasslands Society Occasional Symposium No. 10: 147-150

Clifford, P.T.P.; Rolston, M.P.; Williams, W.M. 1985. Possible solutions to contamination of white clover seed crops by buried seed. Producing Herbage Seeds. Grassland Research and Practice Series No. 2: 67-73.

Culleton, N.; McCarthy, V. 1983. Germination of Lolium perenne, Bromus willdenowii and Trifolium pratense. Irish Journal of Agricultural Research 22: 31-36.

Eaden, J.D. 1980. The role of field inspection in seed certification. Producing Herbage Seeds. Grassland Research and Practice Series No. 2: 99-102.

Easton, H.S.; Cooper, B.M. 1997. Field performance of tall fescue with low infection with Neotyphodium endophyte. pp. 251-253. In: Neotyphodium/Grass Interactions. Eds. Bacon, C.W.; Hill, N.S. Plenum Press, New York \& London.
Easton, H.S.; Couchman, J.N. 1999. Ryegrass endophyte and cattle growth in Northland. Ryegrass endophyte: an essential New Zealand symbiosis. Grassland Research and Practice Series No. 7: 57-62.

Eerens, J.P.J.; Lucas, R.J.; Easton, H.S.; White, J.G.H. 1998. Influence of the ryegrass endophyte (Neotyphodium lolii) in a cool moist environment. I. Pasture production. New Zealand Journal of Agricultural Research 41: 39-48.

Falloon, R.E.; Rolston, M.P. 1990. Productivity of prairie grass (Bromus willdenowii Kunth) affected by sowing date and the head smut fungus (Ustilago bullata Berk.). Grass and Forage Science 45: 357364.

Fletcher, L.R. 1999. "Non-toxic" endophytes in ryegrass and their effect on livestock health and production. Ryegrass endophyte: an essential New Zealand symbiosis. Grassland Research and Practice Series No. 7: 133-139.

Fletcher, L.R.; Sutherland, B.L.; Fletcher, C.G. 1999. The impact of endophyte on the health and productivity of sheep grazing ryegrass based pastures. Ryegrass endophyte: an essential New Zealand symbiosis. Grassland Research and Practice Series No. 7: 11-17.

Froud-Williams, R.J.; Chancellor, R.J.; Drennan, D.S.H. 1984. The effects of seed burial and soil disturbance on emergence and survival of arable weeds in relation to minimal cultivation. Journal of Applied Ecology 21: 629-641.

Garwood, N.C. 1989. Tropical Soil Seed Banks: A Review. pp. 149-209. In: Ecology of Soil Seed Banks. Eds. Leek, M.A.; Parker, V.T.; Simpson, R.L. Academic Press, San Diego.

Gramshaw, D.; Stern, W.R. 1977. Survival of annual ryegrass (Lolium rigidum Gaud.) in a Mediterranean type environment. I. Effect of summer grazing by sheep on seed numbers and seed germination in autumn. Australian Journal of Agricultural Research 28: 81-91.

Hadfield, P.D.; Wynn-Williams, R.B. 1983. Cultivar Management. pp. 281-286. In: Plant Breeding in New Zealand. Eds. Wratt, G.S.; Smith, H.C. Butterworths/DSIR, Wellington.

Harmon, G.W.; Keim, F.D. 1934. The percentage and viability of weed seeds recovered in the feces of farm animals and their longevity when buried in manure. Journal of the American Society of Agronomy 26: 762-767.

Harris, G.S. 1961. The periodicity of germination in some grass species. New Zealand Journal of Agricultural Research 4: 253-260.

Hay, M.J.M. 1994. Autecology of white clover (Trifolium repens $L$.) with special reference to the 
effect of stolon burial on branch formation. $\mathrm{PhD}$ Thesis. Massey University.

Hessberg, V. 1932. Natürliche weisskleeansaat auf weideneuanlagen [The natural sowing of white clover in newly sown down pastures]. Mitteilungen der Deutschen Landwirtschaftsgesellschaft [as seen in Herbage Abstracts, 3, 45] 47: 885-886.

Hodgson, J.; Clark, D.A.; Mitchell, R.J. 1994. Foraging behavior in grazing animals and its impact on plant communities. pp. 796-827. In: Forage Quality, Evaluation, and Utilization. Eds. Fahey, G.C. ASA/ CSSA/SSSA, Madison.

Hume, D.E. 1993. Agronomic performance of New Zealand pastures: implications of Acremonium presence. pp. 31-38. In: Proceedings of the Second International Symposium on Acremonium/Grass Interactions: Plenary Papers.

Hume, D.E.; Barker, D.J. 1991. Natural reseeding of five grass species in summer dry hill country. Proceedings of the New Zealand Grassland Association 53: 97-104.

Hume, D.E.; Chapman, D.F. 1993. Oversowing of five grass species and white clover on a Taupo hill country pumice soil. New Zealand Journal of Agricultural Research 36: 309-322.

Hume, D.E.; Fraser, T.J. 1985. Establishing and managing recent cultivars in arable dryland pastures. Using Herbage Cultivars. Grassland Research and Practice Series No. 3: 45-50.

Hume, D.E.; Lyons, T.B. 1992. Establishment of new pastures free of ryegrass contamination. Proceedings of the New Zealand Grassland Association 54: 151156.

Hume, D.E.; Lyons, T.B. 1993. Methods of establishing tall fescue and ryegrass in a dryland environment. Proceedings of the New Zealand Grassland Association 55: 105-111.

Hume, D.E.; Rolston, M.P.; Baird, D.J.; Archie, W.J.; Marsh, M.R. 1999. Survival of endophyte-infected ryegrass seed buried in soil. Ryegrass endophyte: an essential New Zealand symbiosis. Grassland Research and Practice Series No. 7: 151-156.

Jones, R.M.; Simao Neto, M. 1987. Recovery of pasture seed ingested by ruminants. 3. The effects of the amount of seed in the diet and of diet quality on seed recovery from sheep. Australian Journal of Experimental Agriculture 27: 253-256.

L'Huillier, P.J.; Aislabie, D.W. 1988. Natural reseeding in perennial ryegrass-white clover dairy pastures. Proceedings of the New Zealand Grassland Association 49: 111-115.

Lancashire, J.A. 1978. Improved species and seasonal pasture production. Proceedings of the Agronomy Society of New Zealand 8: 123-127.
Lancashire, J.A.; Brock, J.L. 1983. Management of new cultivars for dryland. Proceedings of the New Zealand Grassland Association 44: 61-73.

Lancashire, J.A.; Rolston, M.P.; Scott, D.J. 1985. Contamination of white clover seed crops by buried seeds. Producing Herbage Seeds. Grassland Research and Practice Series No. 2: 61-65.

Langer, R.H.M. 1977. Pastures and Pasture Plants. A. H. \& A. W. Reed, Wellington. 430 pp.

Lehrer, W.P.J.; Tisdale, E.W. 1956. Effect of sheep and rabbit digestion on the viability of some range plant seeds. Journal of Range Management 9: 118-122.

Lennartz, H. 1957. Über die Beeinflussung der Keimfähigkeit der Samen von Grünlandpflanzen beim Durchgang durch den verdauungstraktus des rindes [The effect of the passage through the alimentary tract of cattle on the viability of seeds of grassland plants]. Zeitschrift für Acker- und Pflanzenbau 103: 427-453.

Lewis, J. 1973. Longevity of crop and weed seeds: survival after 20 years in soil. Weed Research 13: 179-191.

Matthew, C.; Quilter, S.J.; Korte, C.J.; Chu, A.C.P.; Mackay, A.D. 1989. Stolon formation and significance for sward tiller dynamics in perennial ryegrass. Proceedings of the New Zealand Grassland Association 50: 255-259.

McCallum, D.A.; Thomson, N.A.; Judd, T.G. 1991. Experiences with deferred grazing at the Taranaki Agricultural Research Station. Proceedings of the New Zealand Grassland Association 53: 79-83.

McCorkindale, B. 1999. Ryegrass Endophyte - Can we successfully get rid of it? Report on Clutha Monitor Farm Programme. Meat New Zealand/Woolpro.

Milne, G.D.; Moloney, S.C.; Smith, D.R. 1993. Demonstration of dryland species on 90 East coast North Island farms. Proceedings of the New Zealand Grassland Association 55: 39-44.

Ozer, Z. 1979. The influence of passage through sheep and fermentation in dung on the viability of seeds of meadow plants. Weed Research 19: 247-254.

Piggin, C.M. 1978. Dispersal of Echium plantagineum L. by sheep. Weed Research 18: 155-160.

Popay, A.J.; Hume, D.E.; Baltus, J.G.; Latch, G.C.M.; Tapper, B.A.; Lyons, T.B.; Cooper, B.M.; Pennell, C.; Eerens, J.P.J.; Marshall, S.L. 1999. Field performance of perennial ryegrass (Lolium perenne) infected with toxin-free fungal endophytes (Neotyphodium spp.). Ryegrass endophyte: an essential New Zealand symbiosis. Grassland Research and Practice Series No. 7: 113-122.

Prestidge, R.A.; di Menna, M.E.; van der Zijpp, S.; Badan, D. 1985. Ryegrass content, Acremonium endophyte and Argentine stem weevil in pastures in 
the volcanic plateau. pp. 41-44. In: Proceedings of the $38^{\text {th }}$ New Zealand Weed and Pest Control Conference.

Prestidge, R.A.; Pottinger, R.P.; Barker, G.M. 1982. An association of Lolium endophyte with ryegrass resistance to Argentine stem weevil. pp. 119-122. In: Proceedings of the $35^{\text {th }}$ New Zealand Weed and Pest Control Conference.

Prestidge, R.A.; van der Zijpp, S.; Badan, D. 1984. Effects of Argentine stem weevil on pastures in the Central Volcanic Plateau. New Zealand Journal of Experimental Agriculture 12: 323-331.

Rampton, H.H.; Ching, T.M. 1970. Persistence of crop seeds in soil. Agronomy Journal 62: 272-277.

Rice, K.J. 1989. Impact of seed banks on grassland community structure and population dynamics. pp. 211-230. In: Ecology of Soil Seed Banks. Eds. Leek, M.A.; Parker, V.T.; Simpson, R.L. Academic Press, San Diego.

Roberts, H.A. 1986. Persistence of seeds of some grass species in cultivated soil. Grass and Forage Science 41: 273-276.

Rolston, M.P. 1993. Use of endophyte in plant breeding and the commercial release of new endophyte-grass associations. pp. 171-174. In: Proceedings of the Second International Symposium on Acremonium/ Grass Interactions. Plenary Papers.

Sanders, P.M.; Barker, D.J.; Wewala, G.S. 1989. Phosphoglucoisomerase-2 allozymes for distinguishing perennial ryegrass cultivars in binary mixtures. Journal of Agricultural Science 112: 179-184.

Sangakkara, R.; Roberts, E.; Watkin, B.R. 1982. Grass species used and pasture establishment practices in central New Zealand. New Zealand Journal of Experimental Agriculture 10: 359-364.

Shelby, R.A.; Dalrymple, L.W. 1993. Long-term changes of endophyte infection in tall fescue stands. Grass and Forage Science 48: 356-361.

Shelby, R.A.; Schmidt, S.P. 1991. Survival of the tall fescue endophyte in the digestive tract of cattle and horses. Plant Disease 75: 776-778.

Shelby, R.A.; Schmidt, S.P.; Russell, R.W.; Gregory, W.H. 1989. Spread of tall fescue endophyte by cattle Leaflet No. 104. Alabama Agricultural Experiment Station, Auburn University, Alabama.

Siegel, M.R.; Johnson, M.C.; Varney, D.R.; Nesmith, W.C.; Buckner, R.C.; Bush, L.P.; Burrus, P.B., II; Jones, T.A.; Boling, J.A. 1984. A fungal endophyte in tall fescue: incidence and dissemination. Phytopathology 74: 932-937.

Simao Neto, M.; Jones, R.M. 1987. Recovery of pasture seed ingested by ruminants. 2. Digestion of seed in sacco and in vitro. Australian Journal of Experimental Agriculture 27: 247-251.
Simao Neto, M.; Jones, R.M.; Ratcliff, D. 1987. Recovery of pasture seed ingested by ruminants. 1 . Seed of six tropical pasture species fed to cattle, sheep and goats. Australian Journal of Experimental Agriculture 27: 239-246.

Simpson, G.M. 1990. Seed dormancy in grasses. Cambridge University Press, Cambridge.

Smith, D.R.; Slay, M.W.A.; Gray, M.H.; Milne, G.D. 1993. On-farm establishment of drought-tolerant pastures on the east coast of the North Island. Proceedings of the New Zealand Grassland Association 55: 33-38.

Suckling, F.E.T. 1952. Dissemination of white clover (Trifolium repens) by sheep. New Zealand Journal of Science and Technology 33: 64-77.

Suckling, F.E.T. 1965. Hill Pasture Improvement. Newton King Group/DSIR, Palmerston North.

Sutton, C.B. 1996. Successful North Canterbury dairy conversion with quality pasture of nil endophyte ryegrass. Proceedings of the New Zealand Grassland Association 58: 129-131.

Thompson, K.; Grime, J.P. 1979. Seasonal variation in the seed banks of herbaceous species in 10 contrasting habitats. Journal of Ecology 67: 893-921.

Thompson, K.; Grime, J.P. 1983. A comparative study of germination responses to diurnally-fluctuating temperatures. Journal of Applied Ecology 20: 141156.

Uden, P.; van Soest, P.J. 1982. The determination of digesta particle size in some herbivores. Animal Feed Science and Technology 7: 35-44.

Ulyatt, M.J.; Dellow, D.W.; John, A.; Reid, C.S.W.; Waghorn, G.C. 1986. Contribution of chewing during eating and rumination to the clearance of digesta from the ruminoreticulum. pp. 498-515. In: Control of Digestion and Metabolism in Ruminants. Eds. Milligan, L.P.; Grovum, W.L.; Dobson, A. Prentice-Hall, Englewood.

van Vught, V.T.; Thom, E.R. 1997. Ryegrass contamination of endophyte-free dairy pastures after spraydrilling in autumn. Proceedings of the New Zealand Grassland Association 59: 233-237.

Waghorn, G.C.; Reid, C.S.W. 1984. Bloat in cattle. 43. Resting level and vertical displacement of the cranial pillar and other structures in the ruminoreticulum of cattle of known bloat susceptibility. New Zealand Journal of Agricultural Research 27: 481-490.

Waghorn, G.C.; Reid, C.S.W.; Ulyatt, M.J.; John, A. 1986. Feed comminution, particle composition and distribution between the four compartments of the stomach in sheep fed chaffed lucerne hay at two feeding frequencies and intake levels. Journal of Agricultural Science, Cambridge 106: 287-296. 
Waller, R.A.; Sale, P.W.G.; Saul, G.R.; Quigley, P.E.; Kearney, G.A. 1999. Tactical versus continuous stocking for persistence of perennial ryegrass (Lolium perenne L.) in pastures grazed by sheep in south-western Victoria. Australian Journal of Experimental Agriculture 39: 265-274.

Watkin, B.R.; Clements, R.J. 1978. The effects of grazing animals on pastures. pp. 273-289. In: Plant Relations in Pastures. Eds. Wilson, J.R. CSIRO, Melbourne.

White, J.G.H. 1977. Pasture Establishment. pp. 129157. In: Pastures and Pasture Plants. Eds. Langer, R.H.M. A.H. \& A.W. Reed, Wellington.

Widdup, K.H.; Ryan, D.L. 1992. Forage potential of wild populations of perennial ryegrass collected from southern New Zealand farms. Proceedings of the New Zealand Grassland Association 54: 161-165.

Williams, E.D. 1983. Effects of temperature, light, nitrate and pre-chilling on seed germination of grassland plants. Annals of Applied Biology 103: 161-172.
Yamada, T.; Kawaguchi, T. 1971. Dissemination of pasture plants by livestocks. I. Recovery and viability of some pasture plant seeds passed through digestive tract of goats. Journal of Japanese Society of Grassland Science 17: 36-47.

Yamada, T.; Kawaguchi, T. 1972. Dissemination of pasture plants by livestocks. II. Recovery, viability, and emergence of some pasture plant seeds passed through digestive tract of the dairy cow. Journal of Japanese Society of Grassland Science 18: 8-15.

Yamada, T.; Matsuo, S.; Tamura, K. 1972. Dissemination of pasture plants by livestocks. III. Recovery of some pasture plant seeds passed through the digestive tract of beef cattle and emergence of seedlings from seeds recovered from the faeces. Journal of Japanese Society of Grassland Science 18: 16-27. 